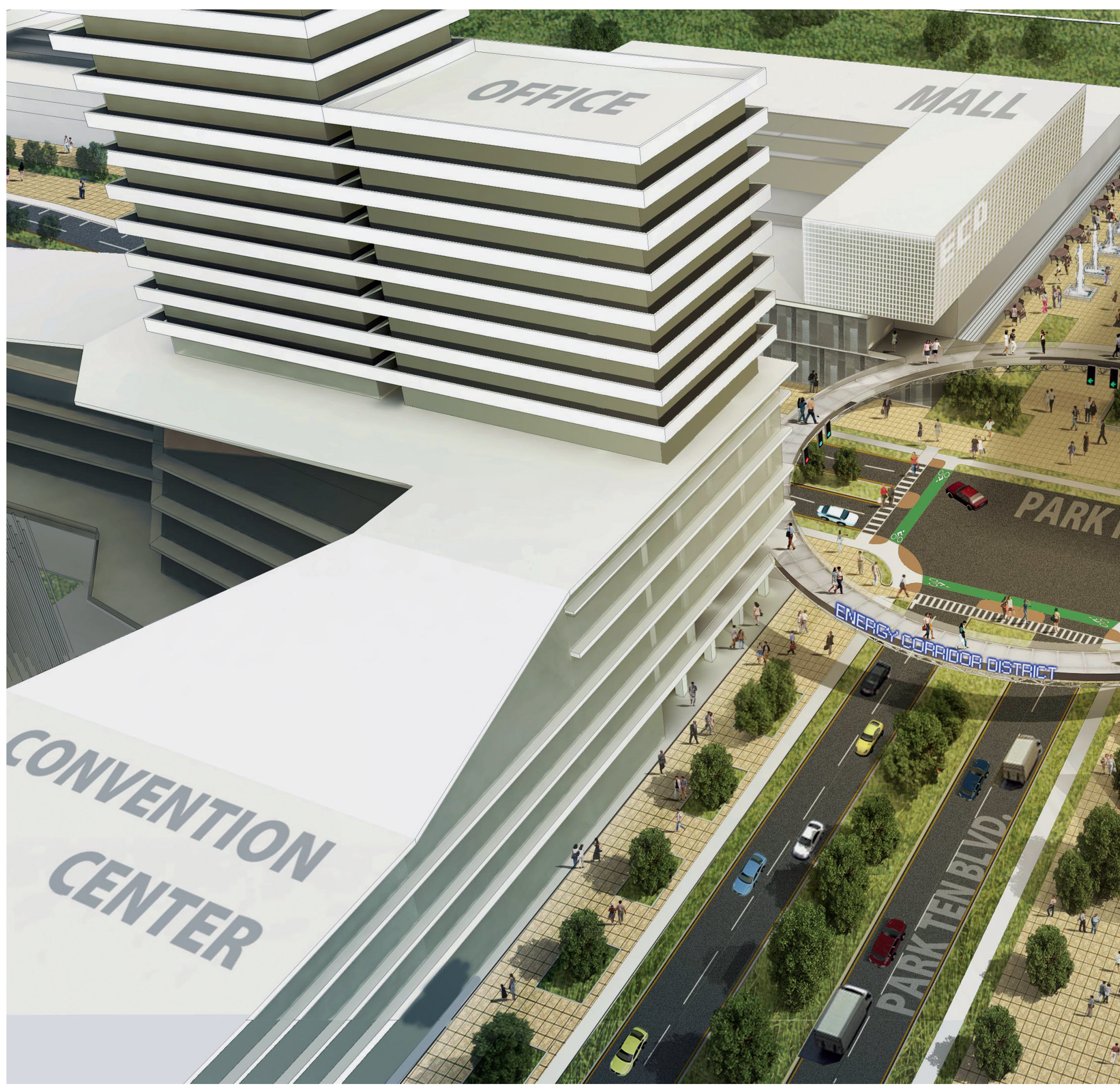




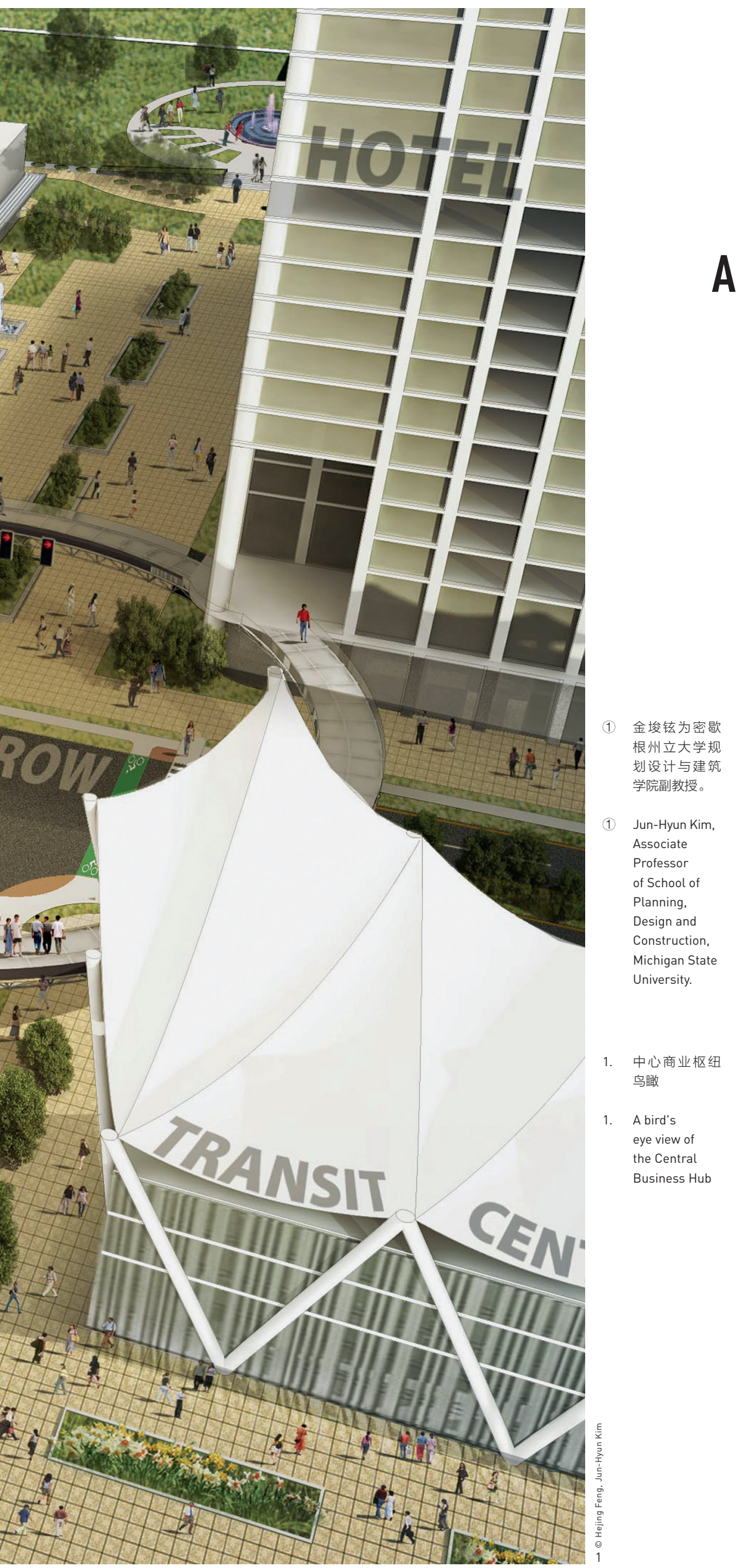

\section{都市走廊的可持续都市主义: 德克萨斯州休斯顿10号园区实证型城市设计 SUSTAINABLE URBANISM FOR A METROPOLITAN CORRIDOR: AN EVIDENCE-BASED URBAN DESIGN FOR PARK 10 IN HOUSTON, TEXAS}

金埈铉 ${ }^{1}$, 盖伦·纽曼, 封赫婧, 杰雷米·梅里尔, 朴钟薰, 市佳荷

Jun-Hyun KIM - Gaten NEWMAN, Hejing FENG, Jeremy MERRILL, Jonghoon PARK, Jiahe BIAN

\section{1 项目背景及场地条件}

快速的城市扩张、人口膨胀和经济增长 带来的无序开发现象已遍及美国各地，同时 也催生出大片功能分配失衡的低密度城市区 域，并引发了一系列环境、社会、卫生和经 济问题。作为一种当代设计模式，可持续城 市开发为解决城市扩张、生活质量下降、经 济增长乏力、气候变化影响等社会 - 环境问 题 ${ }^{[1]}$ 提供了契机。

尽管可持续城市开发能够提升环境质 量、改善人类福祉，但在过去几十年里，大 片城市区域仍采用常规手段进行开发，这种 基于城市扩张的机动车导向型发展模式不 仅未能创造更好的生活环境, 以满足人们 的住房、就业和社会文化需求，也未能维 持自然资源保护和消耗之间的平衡 ${ }^{[2]}$ 。我们 需要采取更加高效、具有弹性的设计方法, 来应对以上挑战，践行一种更加可持续的城 市更新 ${ }^{[3]}$ 。

10 号园区是连接美国德克萨斯州休斯顿 市中部和西部的重要商业走廊（图2）。项目 场地位于德州6号公路、巴克 - 赛普莱斯路和
https://doi.org/10.15302/J-LAF-20170510 收稿时间 RECEIVED DATE / 2016-07-18 中图分类号/ TU98

文献标识码 / B

摘要

该项目旨在为美国德克萨斯州休斯顿市的一处商业区制 定一项综合性总体规划，该规划以可持续都市主义为设计原 则。其主要设计日标是建立一个宜居且可持续的城市商业中 心, 以促进当地经济增长; 同时搌 升该地块对行人和骑行者的友好度。 关键词

可持续都市主义; 街景设计; 低影响开发; 步行和骑行友 好型开发; 能源走廊区

ABSTRACT

This project is to develop a comprehensive master plan incorporating key principles of sustainable urbanism for a business district in Houston, Texas, USA. The main design objectives are to create a livable and sustainable urban business center, to promote economic growth and implement a streetscape design guideline to promote wakkability and bikeability

KEY WORDS

banism; Streetscape Design; Low Impact Development; Walkable and Bikeable Development. Energy Corridor District

整理 汪默英 田晓劼

译 张健

EDITED BY Moying WANG Xiaojie TIAN

TRANSLATED BY Angus ZHANG 
项目地址:

美国德克萨斯州休斯顿市

项目面积:

项目委托:

顿市能源走廊区

首席设计师

金埈铉

六佳荷、封赫婧、刘际星、Thiago Oliveira

设计时间:

2015年5月 2016年4月

所获奖项:

2016ASLA德克萨斯州分会杰出奖

LOCATION:

Houston, Texas, USA

AREA (SIZE):

550 acres

CLIENT:

The Energy Corridor District, Houston

CHIEF DESIGNER

Jun-Hyun Kim

PROJECT TEAM:

Jiahe Bian, Hejing Feng, Jixing Liu, Thiago Oliveira

DESIGN PERIOD

May $2015 \sim$ April 2016

AWARD

2016 Merit Award from the ASLA Texas Chapter

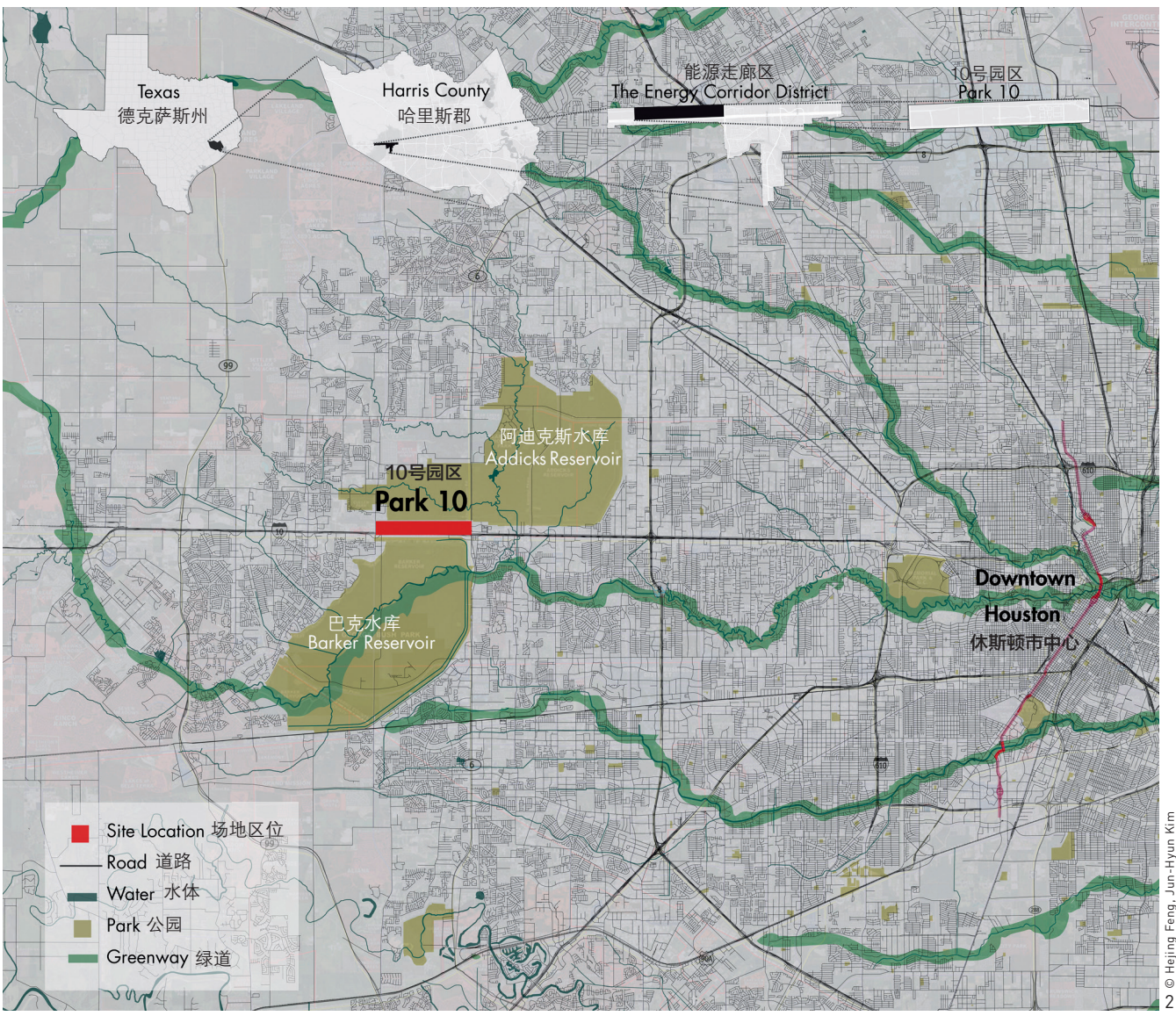

10 号州际公路之间, 其中有 $4 \mathrm{~km}$ 的边界与凯 蒂高速公路相邻。作为一处占地约 $220 \mathrm{hm}^{2}$ 的 高度发达的商业区，10号园区的用地类型主 要为办公用地、工业用地和多户住宅用地, 以及少量商业用地和机构用地 (图3)。为了 实现可持续性城镇化的需求, 10 号园区需建 立一套综合性总体规划, 并寻求振兴城市中 心、改善园区居民生活和工作环境的系统化 途径。项目的首要设计目标是创建一处宜居 且可持续的城市商业中心, 在促进经济增长 的同时, 通过推广一项街景设计指南, 提升 位于中心区域的多功能商业枢纽和位于10号 园区西入口的创新中心两处地块对行人和骑 行者的友好度。

\section{2 问题和挑战}

\section{1 土地利用问题}

10号园区内的办公区、住宅区和商业区
大多彼此分离、各自独立, 这使得场地结构 更像是一种脱节的拼凑组合, 而非一体化的 网络。土地功能的隔离和混合功能开发途径 的缺失也降低了场地的价值。

\section{2 连通性和可达性问题}

场地内现有社区的碎片化和正在进行 的开发计划迫使居民、区内员工和游客的单 人驾驶机动车数量居高不下。目前, 城市大 型街区形成的开发布局限制了场地的机动车 通达性, 空间环境对行人和骑行者也并不友 好。尚不完善的运输系统、曲折的街道、随 处可见的死胡同、之味的街景和落后的道路 指引设施, 致使当地街道环境嘈杂、交通负 荷沉重, 更存在着诸多安全隐患。

\section{3 空间营造问题}

10号园区内之味的街景和存在安全隐患 的十字路口使得居民、区内员工和游客（包 
括行人、自行车及摩托车骑行者, 以及公共 交通使用者）不愿利用场地内的现有功能。 此外, 由于缺少具有吸引力的户外空间, 公 园很难与周边社区产生互动。因此, 多数人 更倾向于留在自己的办公室或家中, 而远离 公共交流、公众参与和社会互动。

\section{4 环境问题}

快速的城市发展吞噬了大片曾经的绿 地, 导致生物多样性和物种丰富度锐减。由 于研究区域毗邻两座保存完好的大型水库, 所以在区域内建立一条连接两座水库的绿道 十分必要。其不仅能够吸引人们亲近自然, 同时也有益于野生动物在此生存繁衍。此 外, 成比例增加的不透水面层导致该地区的 渗透率降低, 继而使雨水径流量高于开发前 水平, 增加了项目区域内的洪水风险。一旦 地下水供应不足, 低渗透率还可能导致一系 列长期问题。

\section{3 设计目标及设计策略}

为了应对上述挑战和问题, 项目提出了 一项综合性总体规划, 并以可持续都市主义 为设计原则, 打造商业节点、制定街景设计 指南和构建绿色网络 (图4)。规划方案在三 个主要入口和具有混合功能的办公区及社区 中心设置商业组团节点, 以创造目标场地并 增强场所感。基于大量场地分析, 设计团队 建立了一套街景设计指南, 以建立更加高效 的街道网络系统, 整合多种交通工具, 优化 步行和骑行环境的连通性和可达性。一座中 央公园和各种较小尺度的多功能绿地将组成 一个绿色网络。同时, 公园还运用低影响开 发技术调节雨水径流, 并使用降噪设施和节 能设施实现节能设计。

\section{1 设计目标}

10号园区的建设亟待现有社会 - 经济、 环境和城市设计背景的转型。为了应对该都 市走廊的复杂性, 总体规划对社会、经济和 环境条件进行了系统性、协同性的重组, 以 促进该都市走廊长期的精明增长并提升区域

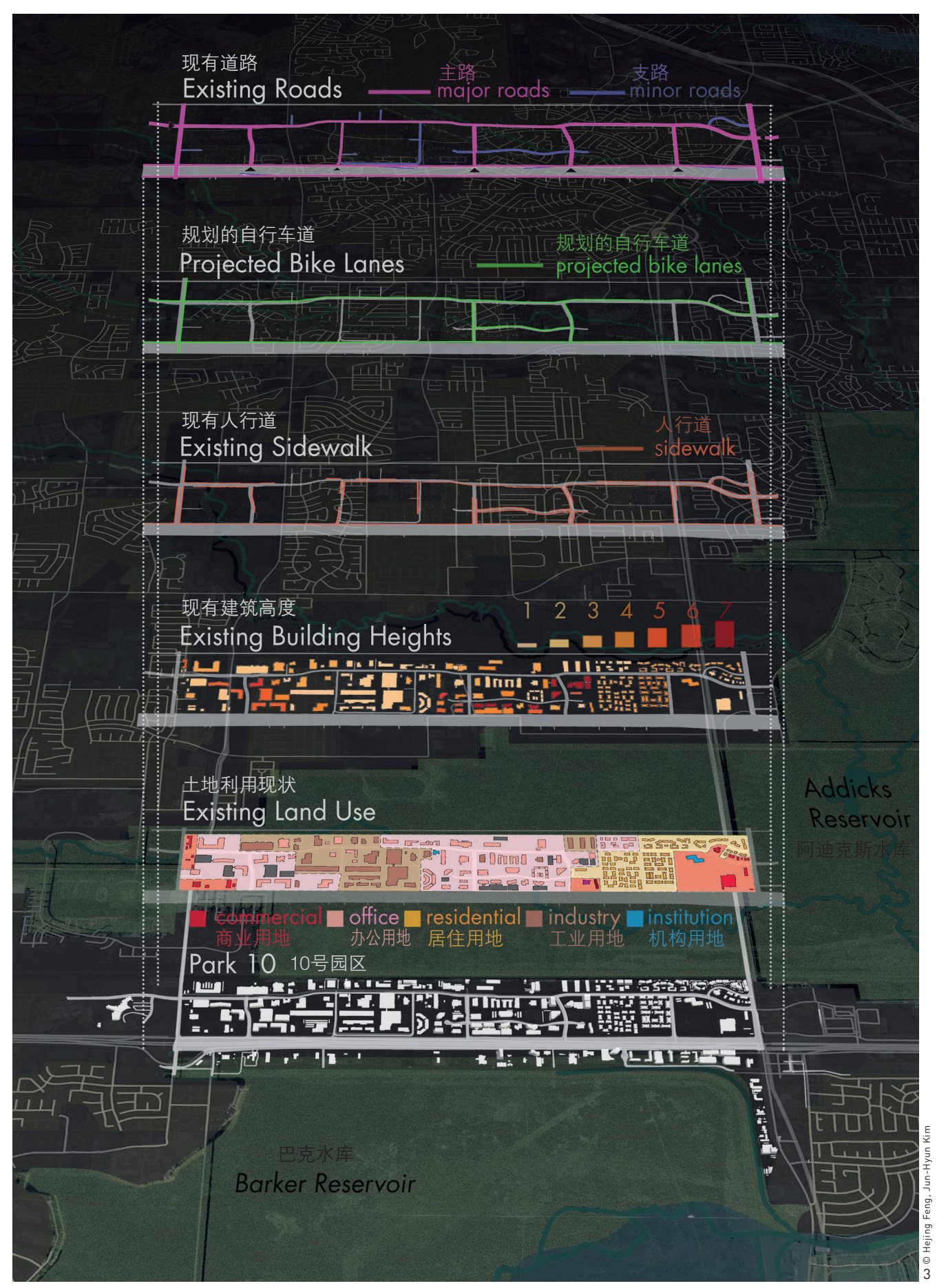

活力。总体规划确定了5个主要目标：1) 创 建一座宜居社区；2）建立社会 - 经济枢纽;

3) 整合多模式运输系统; 4) 推行环境友 好型响应式开发模式；5）开发节能设计 ( 图5）。 


\section{2 街景设计指南}

街景设计是城市开发中最重要的元素之

一。精心设计的街景能够为社区居民带来诸 多裨益, 包括改善身心健康和促进经济增 $k^{[4]}$ 。10号园区目前采用的是机动车导向型 传统开发模式，这使得该区域缺乏场所感、 视觉品质低下, 且无法完全支持区域内居民 及区内员工的步行和骑行活动。若要重建地 块并使其恢复活力, 必须践行新的可持续社 区规划和街景设计。为实现这一目标, 指南 必须推广高效的设计原则并建立宜居且可持 续的城市开发模式。经过深入的场地调研,

设计团队建立起一套系统化的街景设计指 南。依据对包括道路区位、道路宽度、道路 长度、交通流量、周边土地利用和未来需求 这6个主要阈值进行评分, 10 号园区及邻近 地区 (包括休斯顿能源走廊区) 的所有街道 被划分为三个等级（图6 8)。

依照街景设计指南的要求, 总体规划连 接并拓宽了人行道, 同时引入自行车道和配 套街道设施。为了增强当地社区的认同感, 营造丰富多彩的社区活动, 项目创建了各式 富有吸引力的目标场地。此外, 通过应用低 影响开发技术，不透水区域总面积得以减 少, 继而削弱了地表径流。
总体规划采用了一系列多样的交通稳 静化设施, 以应对由车辆交通带来的安全问 题。此外, 为了确保安全的步行和骑行环 境, 最终方案提出了一种新型的步行导向型 街道——“线性公园街”，并在其中设置多 样化的设计模块, 使其连接起街道网络中的 一系列目标场地。这种设计方法创建了设施 完善的街道, 确保了行人和骑行者的出行安 全和舒适度。最后, 街景设计指南还旨在提 升土地价值, 以振兴当地经济（图9)。

\section{3 低影响开发与绿色网络体系}

10号园区的设计旨在将场地中的水文流 量尽可能地维持在场地开发前水平。公园应 用了生物滞留设施、生态洼地、雨水花园、 贮水池、渗水沟、缓冲带和绿色屋顶等多种 场地设计技术 ${ }^{[5]}$ 。这些低影响开发设施被设置 在私人和公共空间中, 在靠近水源处提供就 地渗透和储水功能。此外, 综合性总体规划 还将打造一个绿色网络, 以便于人们进入邻 近的休闲性开放空间, 同时提高场地中的绿 地总量。

\section{4 集中区设计}

如上所述, 设计主要集中于两大区域:

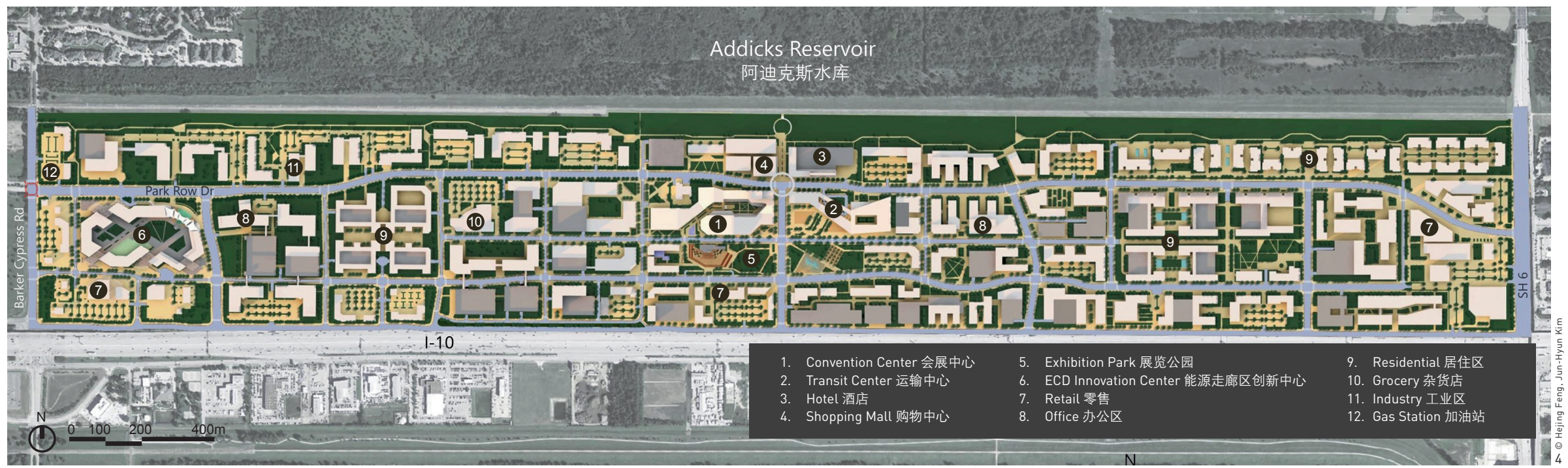




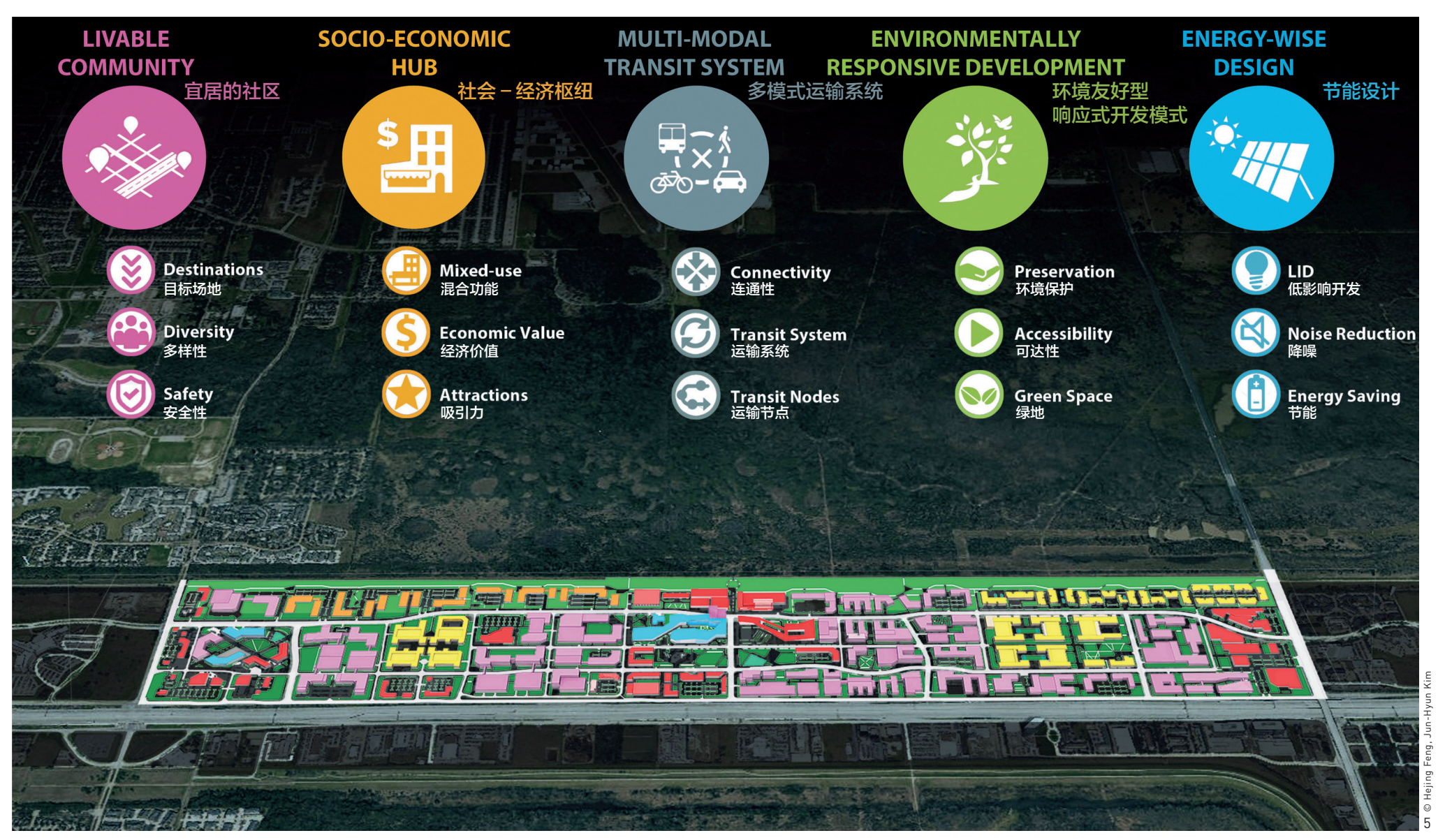

4. 总体规划平面图

5. 设计目标

4. Comprehensive master

plan

5. Design goals
位于中心区域的多功能商业枢纽，以及位于 10号园区西入口的创新中心 (图10)。

\subsection{1 中心商业枢纽}

该区域的三个设计目标为：1）打造包 含混合用地和多种目标场地的充满活力且宜 居的城市商业中心；2）通过规划网格状街 道和改善街景，增强该区域的连通性和可达 性；3）建立起开放空间与娱乐设施之间通 畅连接的网络。该项目创建了一个多功能商 业中心，它既是设有会议厅和展览空间的会 展中心，又是多模式运输中心，同时也是鼓 励居民开展户外活动、促进积极生活方式的 公园系统（图1，11）。

\subsection{2 创新中心}

创新中心的设计包括三个主要设计目 标：1）通过丰富土地利用类型, 以及对办
公区、展览区、美术馆、公用空间和商业空 间进行创新性组合, 创造一处具有吸引力的 园区副中心；2）根据现有的道路网络和规划 的建筑形式及功能, 为项目场地 (尤其是道 路交叉口和碎片化区域）创建温馨怡人的空 间；3）通过打造设施完善的街道和设立地标 来巩固步行和骑行网络。所有的设计最终都 以支持和优化积极的社区目标型理念为导向 (图12)。

\section{4 项目效益与成本节约}

总体设计方案通过运用低影响开发, 为 经济增长、社会互动和生态环境带来了诸多 裨益。网格状的街道规划与街道完善策略相 结合, 为场地内的居民和员工提供了迷人的 街景和愉悦的步行和骑行体验。根据现有数 据量和资源量, 设计策略带来的效益能够被 
PLANNING STRUCTURE — LOCATION 规划结构一一道路位置

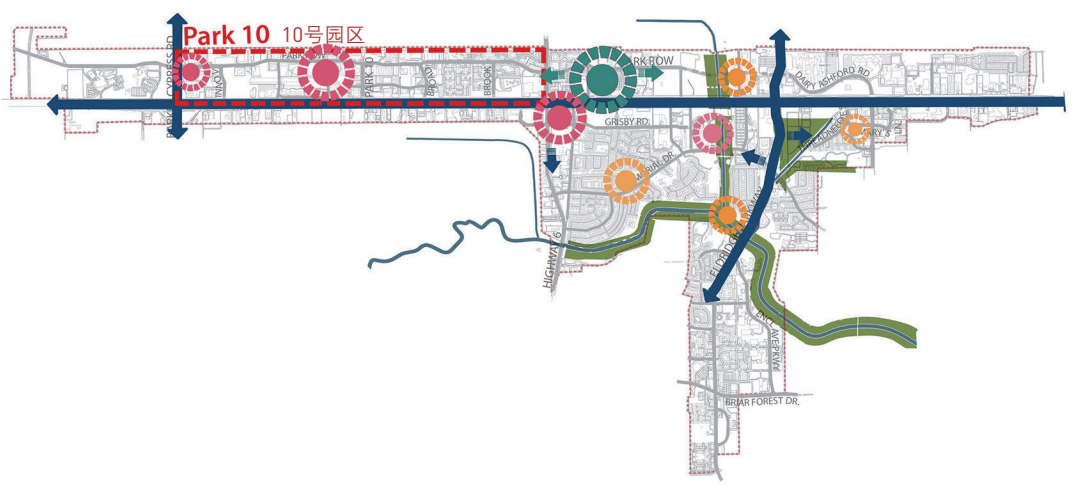

ROAD WIDTH

道路宽度

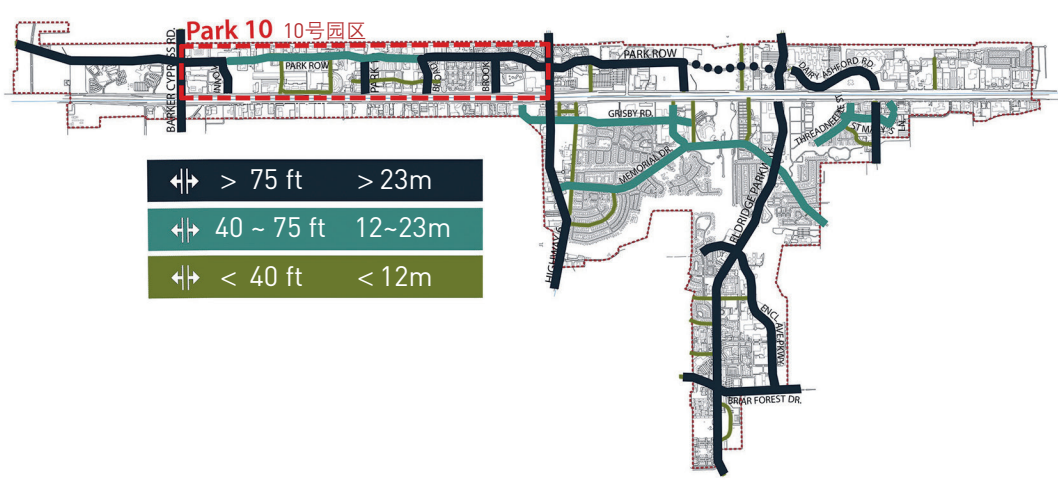

ROAD LENGTH

道路长度

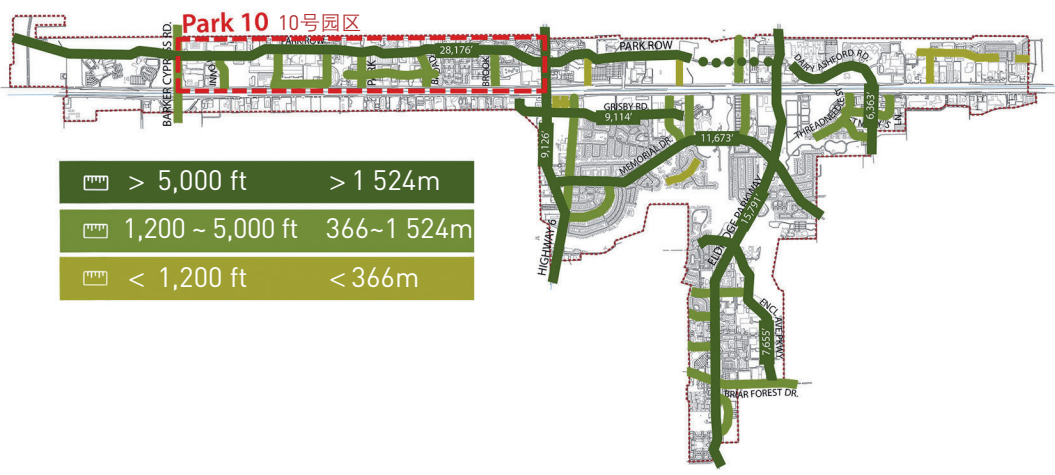

SURROUNDING LAND USE

周边土地利用

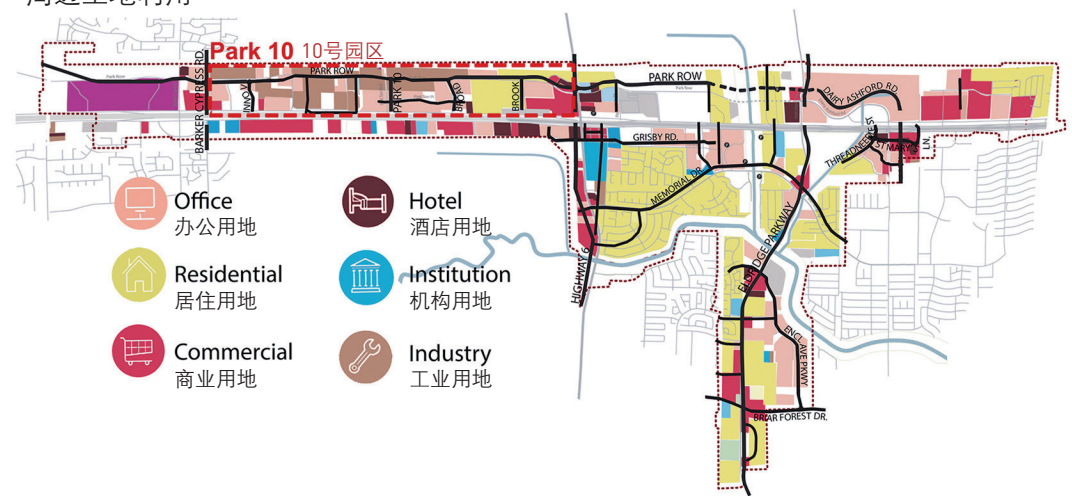

TRAFFIC VOLUME (per day) 交通流量 (每天)

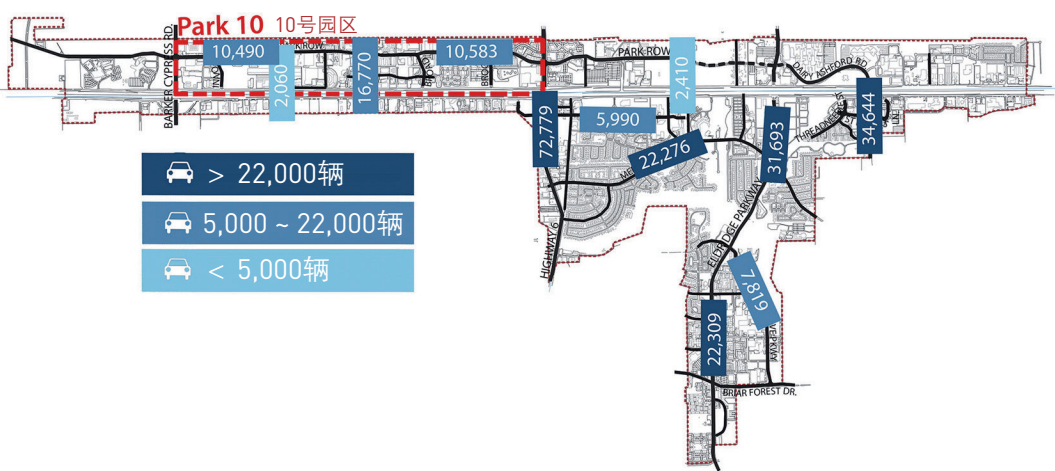

DEVELOPMENT URGENCY — FUTURE DEMAND 发展紧迫性一未来需求

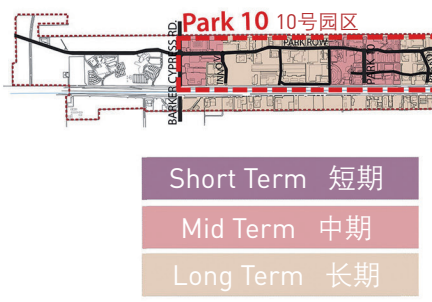

量化。最终方案每年可节省超过22 000美元 的水处理费用, 而在绿色网络系统中新栽植 的树木，在雨洪管理成本和提升二氧化碳吸 收量方面每年预计节约 86 万美元。在社会效 益层面, 最终方案新建了长达 $38 \mathrm{~km}$ 的自行车 道, 并将人行道总长增加了约8倍 ( 从 $5.4 \mathrm{~km}$ 增至49.6km），这不仅促进了社区居民锻炼 身体的积极性, 也在10号园区内创造了更多 社交互动的机会。最后, 设计规划还计划设
立新的办公区、混合用地及住宅区，这将为 该区域带来巨大的经济效益，使现有条件下 的区域租金总收入从3.56亿美元提高到5.33

亿美元。LAF

\section{致谁}

感谢能源走廊区总经理克拉克・马丁森先生、城市规划师法比亚 娜・德玛利女士、董事长大卫・海托沃先生以及景观设计师刘际星 女士和城市规划师蒂亚戈・奥利维拉先生对本文的支持和帮助

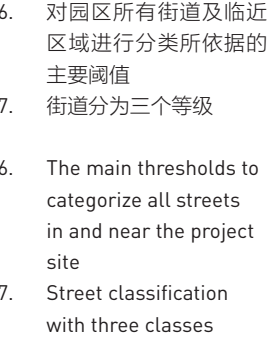




\section{Project Background and Site Contexts}

The current pressures of rapid urban sprawl, population expansion and economic growth have made uncontrolled development a common phenomenon throughout the United States. These pressures have also created large, low-density urban areas with unevenly distributed functions, which, in turn, have generated environmental, social, sanitary and economic problems. Sustainable urban development, as a contemporary design paradigm, provides opportunities to deal with socio-environmental issues such as urban sprawl, decrease of quality of life, weakness of economic growth and the impacts of climate change ${ }^{[1]}$.

Although sustainable urban development can improve environmental quality and promote human well-being, many urban areas were developed conventionally with typical urban sprawl and auto-dependent development in the last decades which failed to meet the expectations of creating better living environments in regards to housing, employment, and social and cultural needs; simultaneously, the balance between natural resource protection and use has not been maintained either ${ }^{[2]}$. To respond to these challenges, more effective and resilient design approaches are required for a more sustainable urban renewal ${ }^{[3]}$

Park 10 is a primary business corridor linking central and west Houston, Texas, USA (Fig. 2). The project site is delineated by Texas State Highway 6, Barker Cypress Road and Interstate Highway 10, with about 2.6 miles of frontage on the Katy Freeway Covering an area of 550 acres, Park 10 is a highly developed business district dominated by office, industry and multi-family land uses, as well as low proportion of commercial and institution areas (Fig. 3). To meet sustainable urbanization demands, the comprehensive master plan for the Park 10 area must

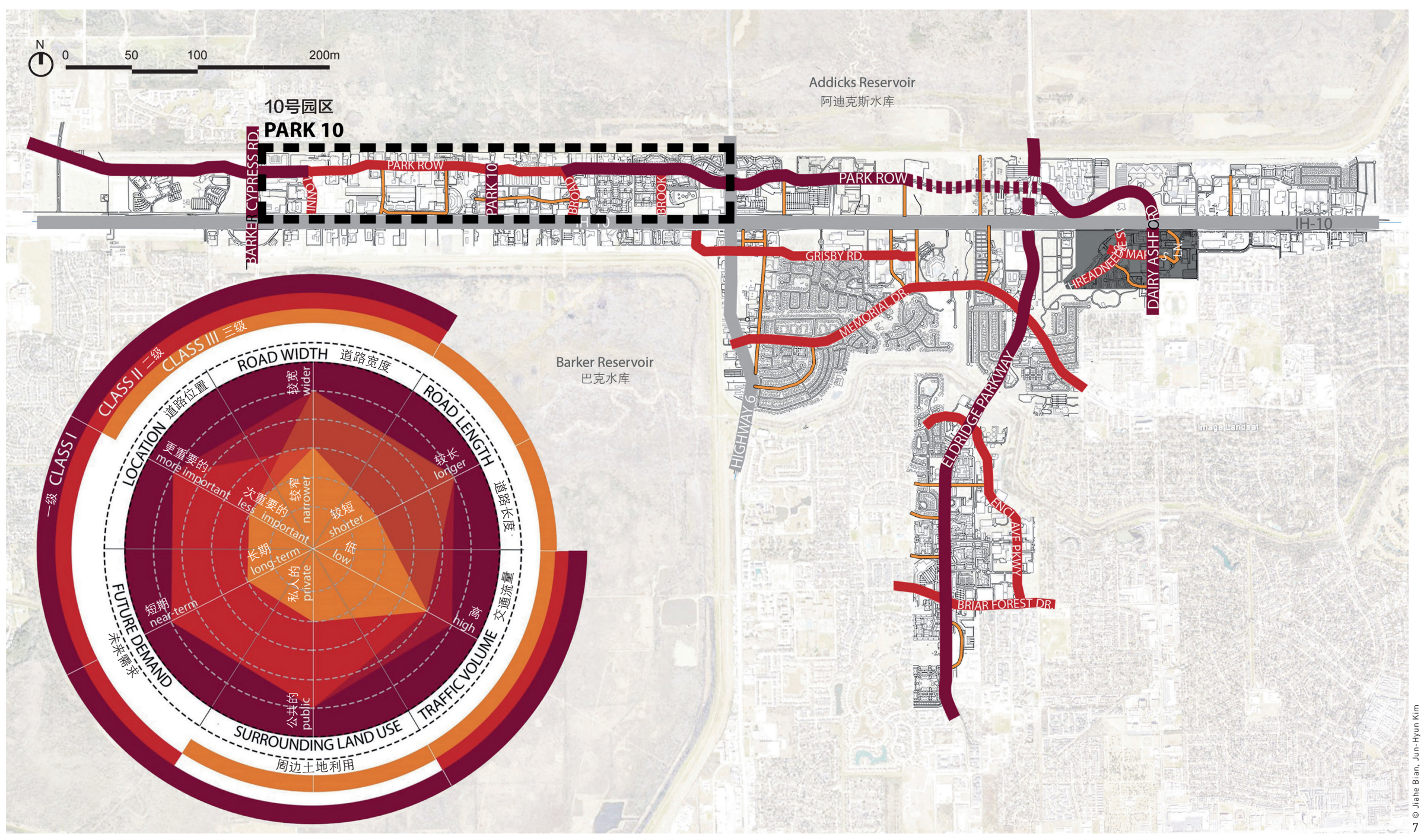



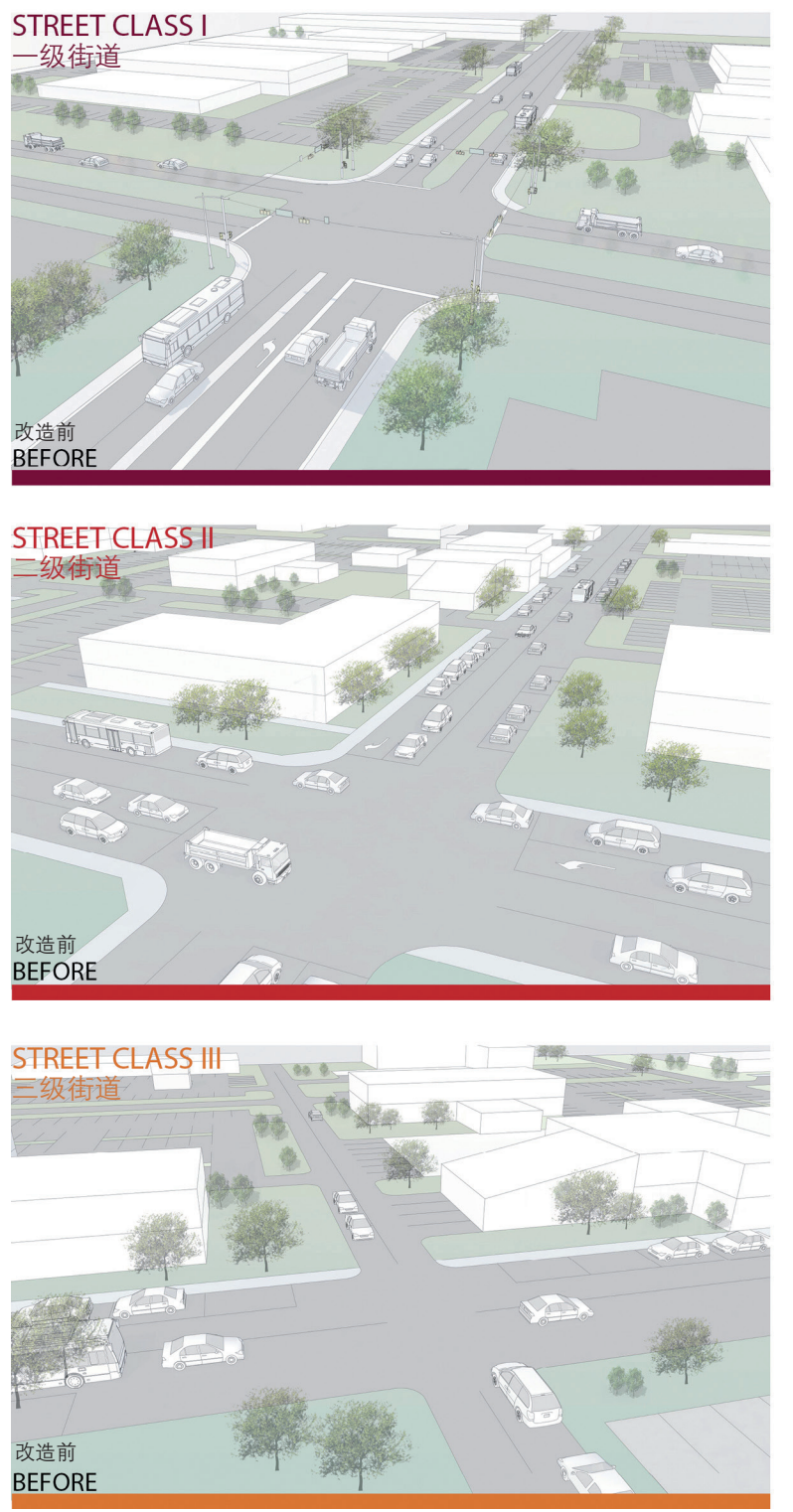
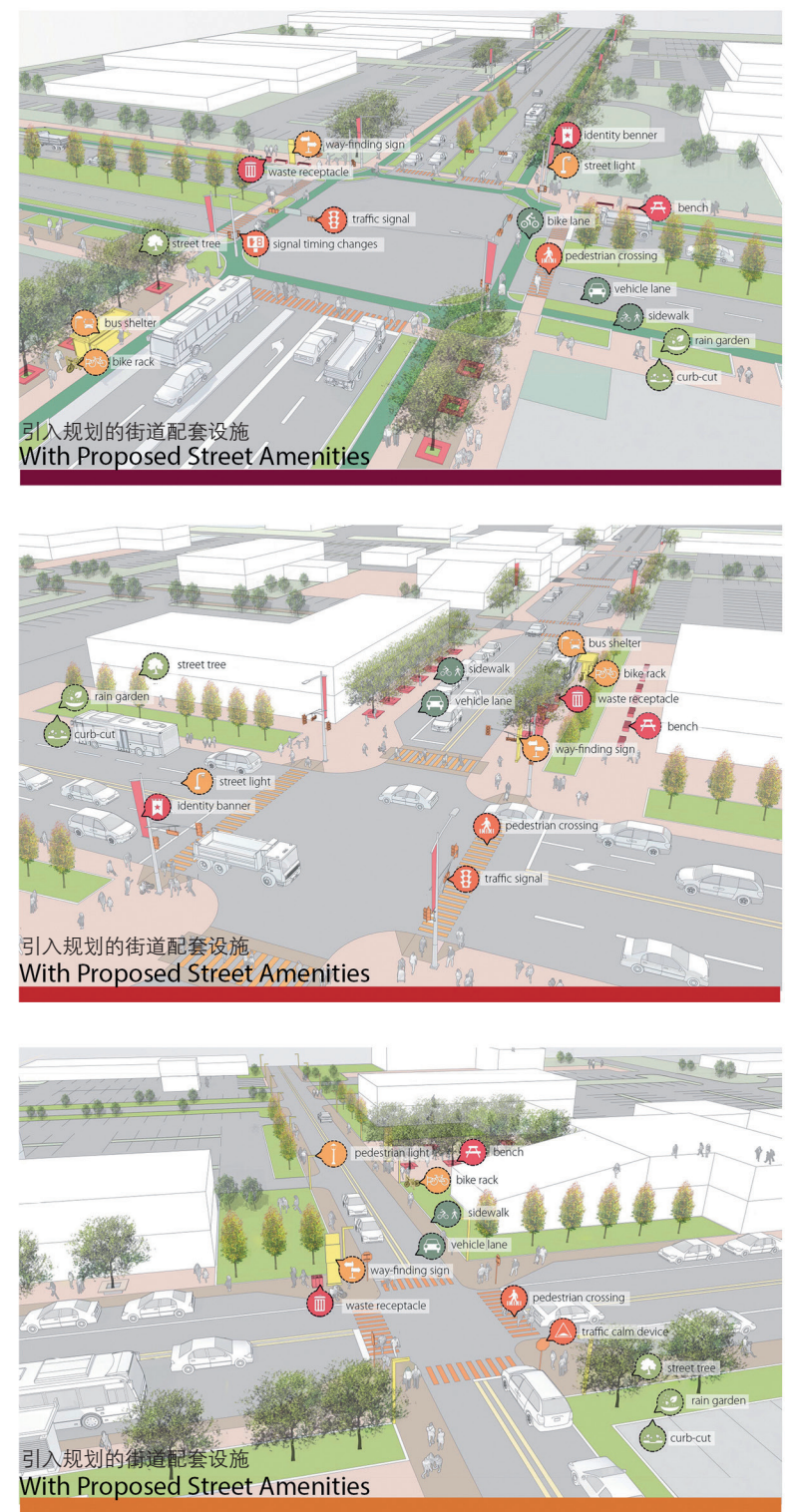
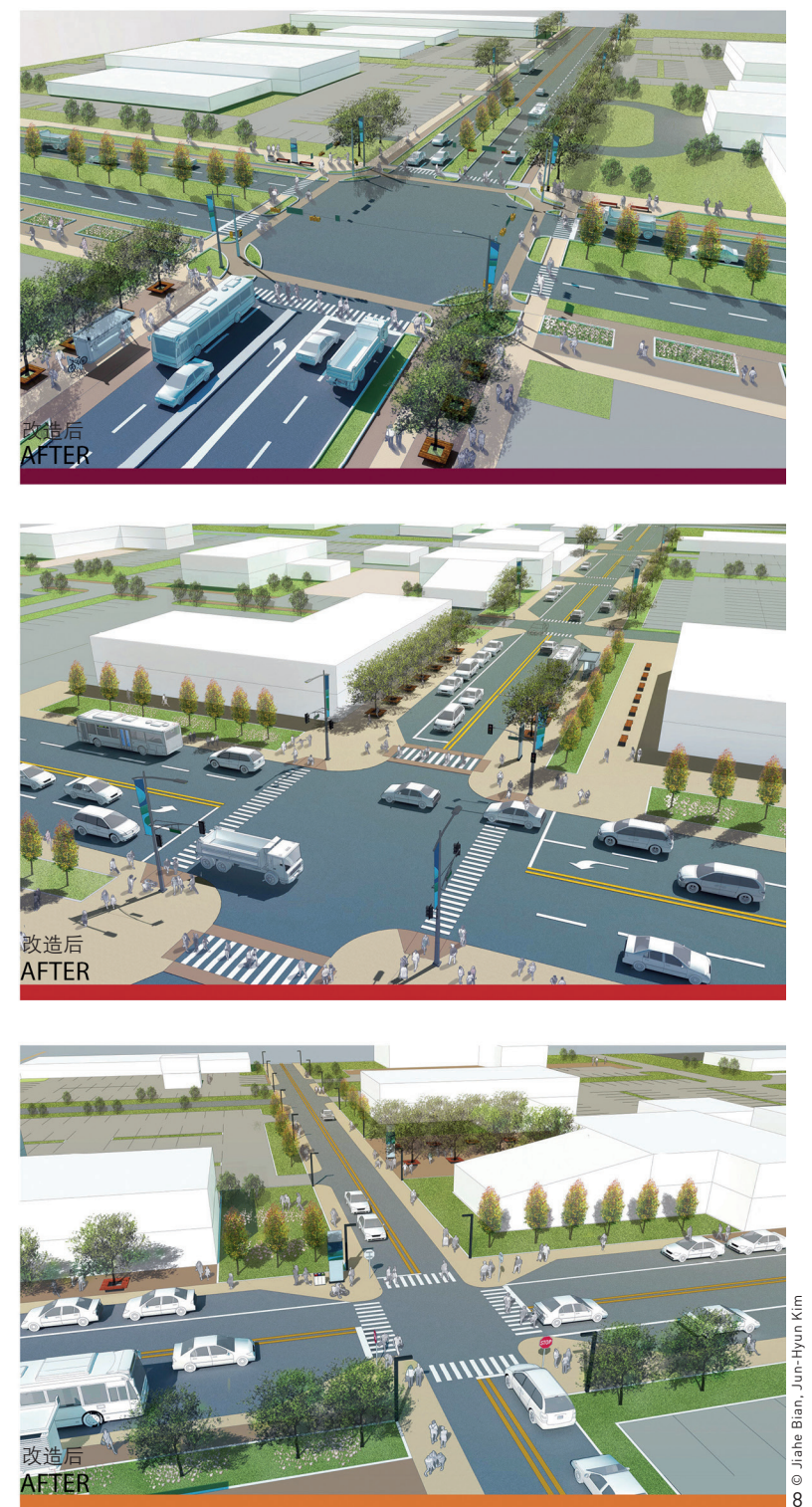

seek a systematic approach to revitalize urban centers and to improve the living and working environment. The main design goals are to create a livable and sustainable urban business center to promote economic growth, and to apply a specific streetscape design guideline into a multifunctional business hub located in the central area, and an innovation center at the west entrance of Park 10 to promote walkability and bikeability there.

\section{Issues and Challenges}

\subsection{Land Use}

The office, residential and commercial areas inside of Park 10 are mostly separated and independent of each other, making the configuration a detached patchwork instead of an integrated network. Both the isolation of land uses and absence of mixed-use development approaches degrade the value of the site.

\subsection{Connectivity and Accessibility}

The incoherence of the existing

neighborhood and the on-going development plans force residents, employees and visitors to be highly single occupancy vehicleoriented. Currently, the large urban blocks are often created in a development pattern, resulting in both limited accessibility for vehicles and unfriendly environment for pedestrians and cyclists. The incomplete transit system with roundabout streets, dead 
8. 三个等级的街道施行街 景设计前后对比图

9. 规划的步行导向型街道 设计模型

8. Before and after views of streetscape design proposals for each class of the street

9. Proposed pedestrianoriented streetscape design modules ends, lack of attractive streetscape and wayfinding facilities creates noisy, heavy traffic loads and safety issues.

\subsection{Place-making}

The unattractive streetscape and unsafe intersections in Park 10 make citizens, employees and visitors lincluding pedestrians, bicyclists, motorists and transit riders) unwilling to become involved in current functions in the site. Further, without appealing outdoor spaces, there is little incentive for community interaction.

As a result, people prefer to stay in existing buildings and keep away from public communication, participation, and social interaction.

\subsection{Environmental Problems}

Rapid development has devoured much of the previous green space, resulting in decreases of bio-diversity and species richness. Since the study area is tangential to two large preserved reservoirs, there is a need for the creation of greenways, not only for people to access nature but also for wildlife to thrive. In addition, proportional increasing impervious surfaces result in
क

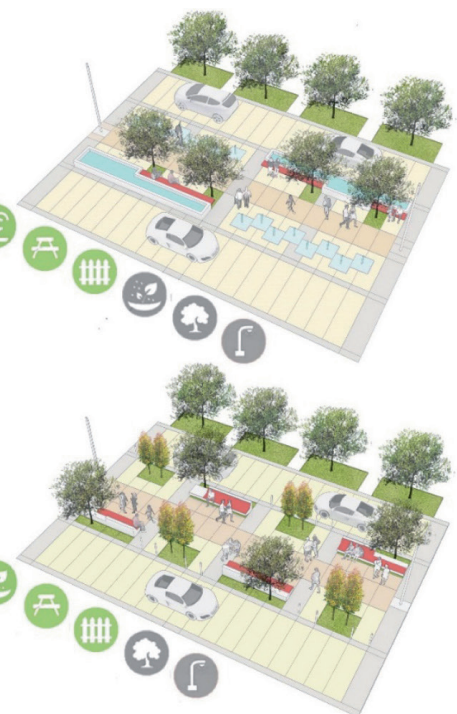

중
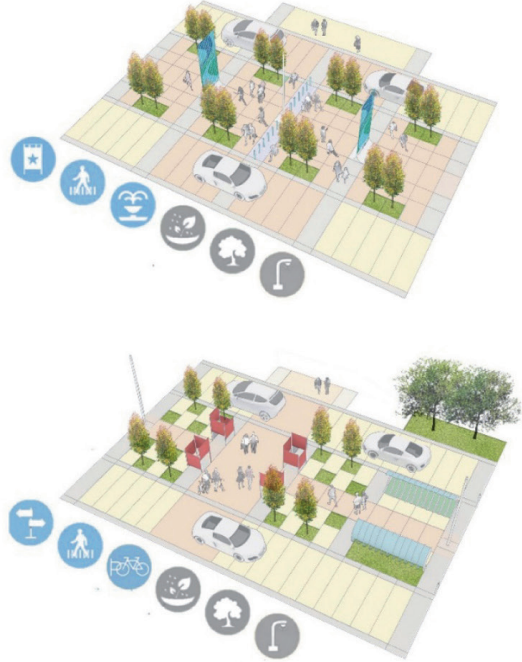

comfort and identity 舒话感和归属感 嶰适感和 可达性和连接性 达性和连推

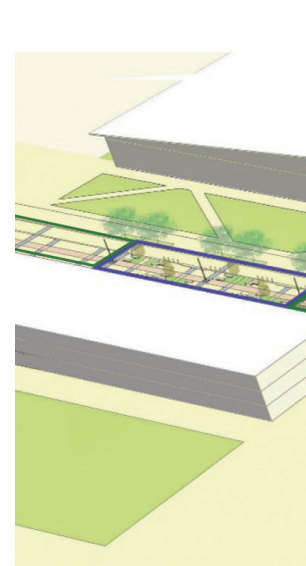

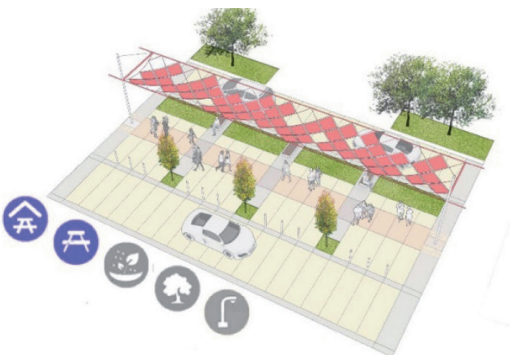

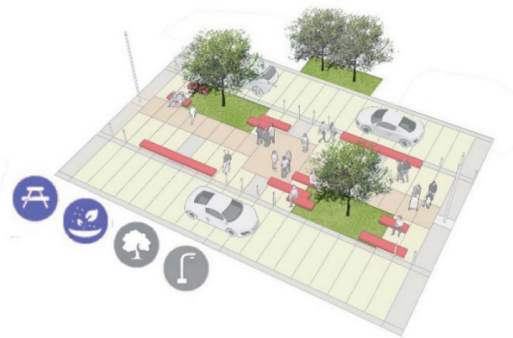

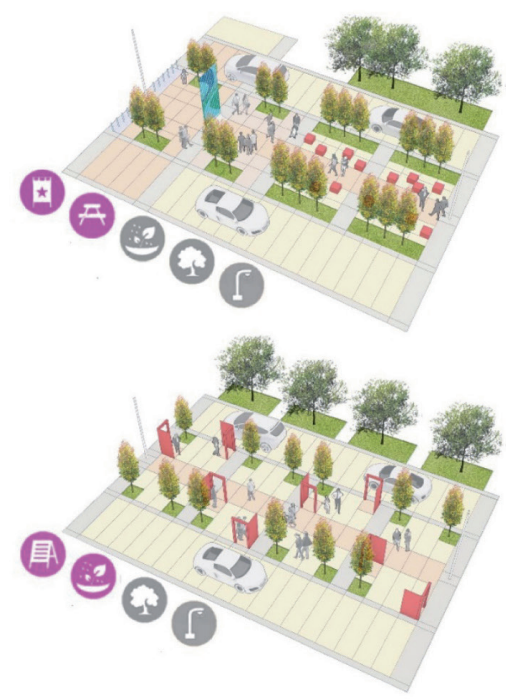

art and activities 艺术体验和各式活动 


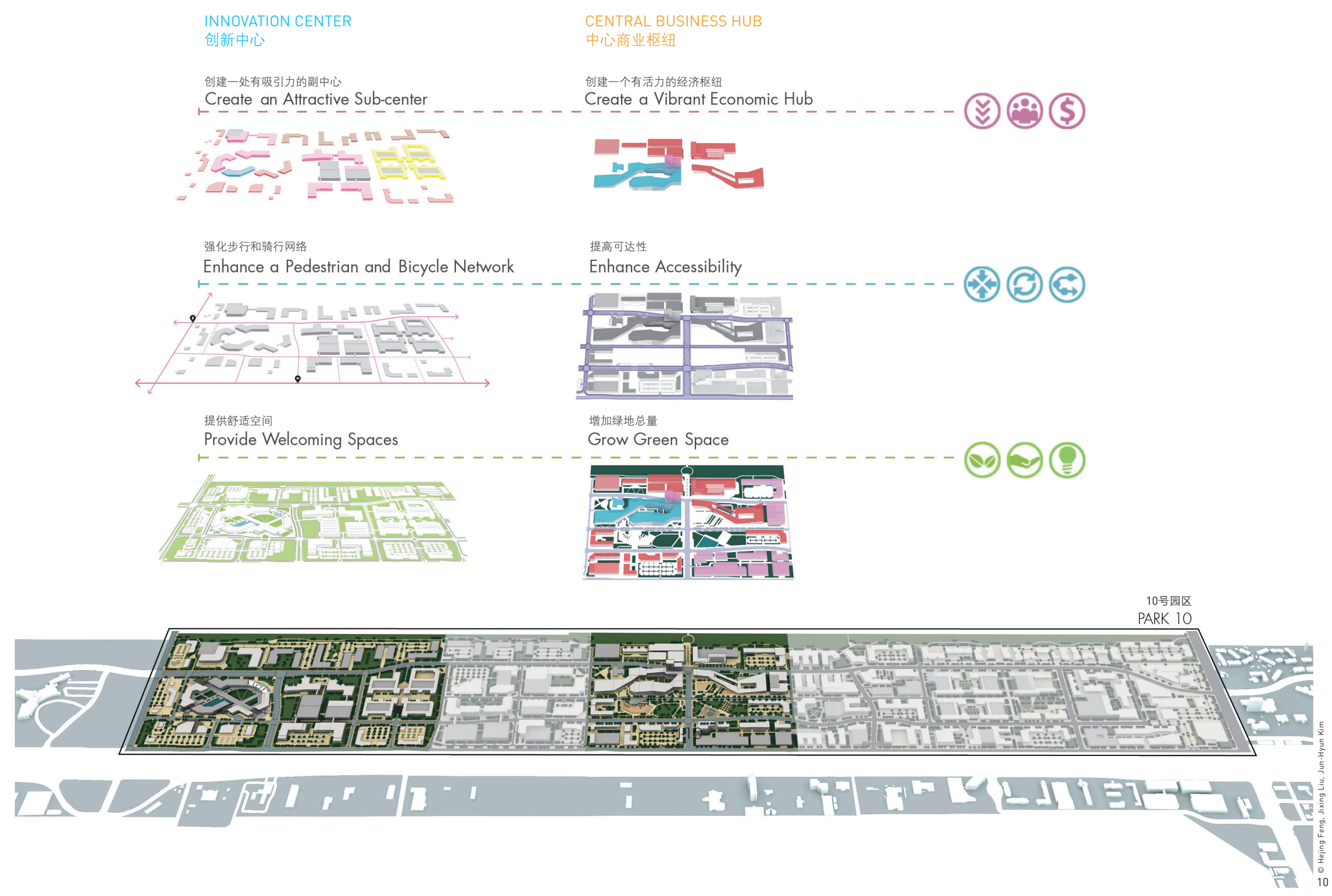

a lower infiltration rate, causing higher stormwater runoff volumes than that in predevelopment levels that increases the flood risk in the project area. The low infiltration rate will also lead to long term problems since the groundwater may not be recharged.

\section{Design Goals and Strategies}

To respond to the aforementioned challenges and issues of Park 10 , this project proposes a comprehensive master plan incorporating key principles of sustainable urbanism, including commercial nodes, a streetscape design guideline and a green network (Fig. 4). Commercial cluster nodes are proposed at the three main entrances and the mixed-use office and community centers to create destinations and to reinforce a sense of place. Based on the extensive site analysis, a streetscape design guideline is developed to establish a more effective street network system which integrates multiple modes of transportation and provides a higher level of pedestrian and bicyclist connectivity and accessibility. The green network is proposed with a central park and various smaller scaled multi-functional green spaces. Low impact development (LID) techniques are implemented to regulate stormwater runoff while noise reduction facilities and energy saving applications are used to achieve an energy-wise design.
10. 两个集中区域的设计 方案

10. Design concepts for two concentration areas 


\subsection{Design Goals}

The Park 10 development requires a transformation of the existing socioeconomic, environmental and urban design settings. To address the complexity of the metropolitan corridor, the master plan adopts a systemic and synergistic reorganization of social, economic and environmental considerations that enhances a long-term smart growth and the vitality of the urban corridor. Five major goals are identified: 1) creating a livable community; 2) locating a socio-economic hub; 3 ) integrating a multi-modal transit system; 4) producing an environmentally responsive development; and 5) developing an energywise design (Fig. 5).

\subsection{Streetscape Design Guideline}

Streetscape design is one of the most important elements for urban development. A well-designed streetscape provides a number of benefits to community members including improving mental and physical health and economic growth ${ }^{[4]}$. The existing development of Park 10 employs a conventional urban development approach focusing on vehicle-oriented design. As a result, the area lacks of sense of place, possesses a poor visual quality and does not fully support walkable and bikeable activities for residents and employees. New sustainable neighborhood plans and streetscape designs are necessary to renovate the area, to restore its vibrancy and to deploy effective design principles and create a livable and sustainable urban development. Following an in-depth site investigation, a systematic streetscape design guideline is developed. All streets within Park 10 and the adjacent areas, including the Houston Energy Corridor District (ECD), are categorized into three classes, which are determined by using a scoring system with six major thresholds regarding location, road widths, road lengths, traffic volume, surrounding land uses and future demand (Fig. $6 \sim 8$ ).

Based on the streetscape design guideline, the master plan connects and broadens sidewalks, while integrating bike lanes with appropriate street amenities. To enhance the local neighborhood identity and encourage vibrant community events, a variety of attractive destinations is also proposed. Moreover, the implementation of LID technologies decreases the total amount of impervious areas and reduces surface runoff.

Safety issues resulting from vehicular traffic are dealt with using a series of diverse traffic calming devices. In addition, to secure safe walking and biking environments, the design proposes a new pedestrian-oriented street, called the Linear Park Street, with multiple design modules to create an interconnected street network linking a series of destinations. This approach offers complete streets to secure the safety and comfort of pedestrians and bicyclists. Finally, the proposed streetscape design guideline aims to increase land value and to bring economic prosperity (Fig. 9).

\subsection{LID and Green Network System}

Park 10 is designed to maintain, as much as possible, the hydrological flow in the existing site compared with predevelopment status. Several site design techniques are applied, such as bio-retention facilities, bioswales, rain gardens, cisterns, infiltration trenches, buffer strips and green roofs ${ }^{[5]}$. These LID elements are installed in private and public spaces, providing on-site infiltration and storage of water close to the source. In addition, the comprehensive master plan proposes a green network with easy access to adjacent recreational open spaces, while increasing the total amount of green space of the site.

\subsection{Concentration Area Designs}

As noted, the design includes two concentration areas, a multifunctional 


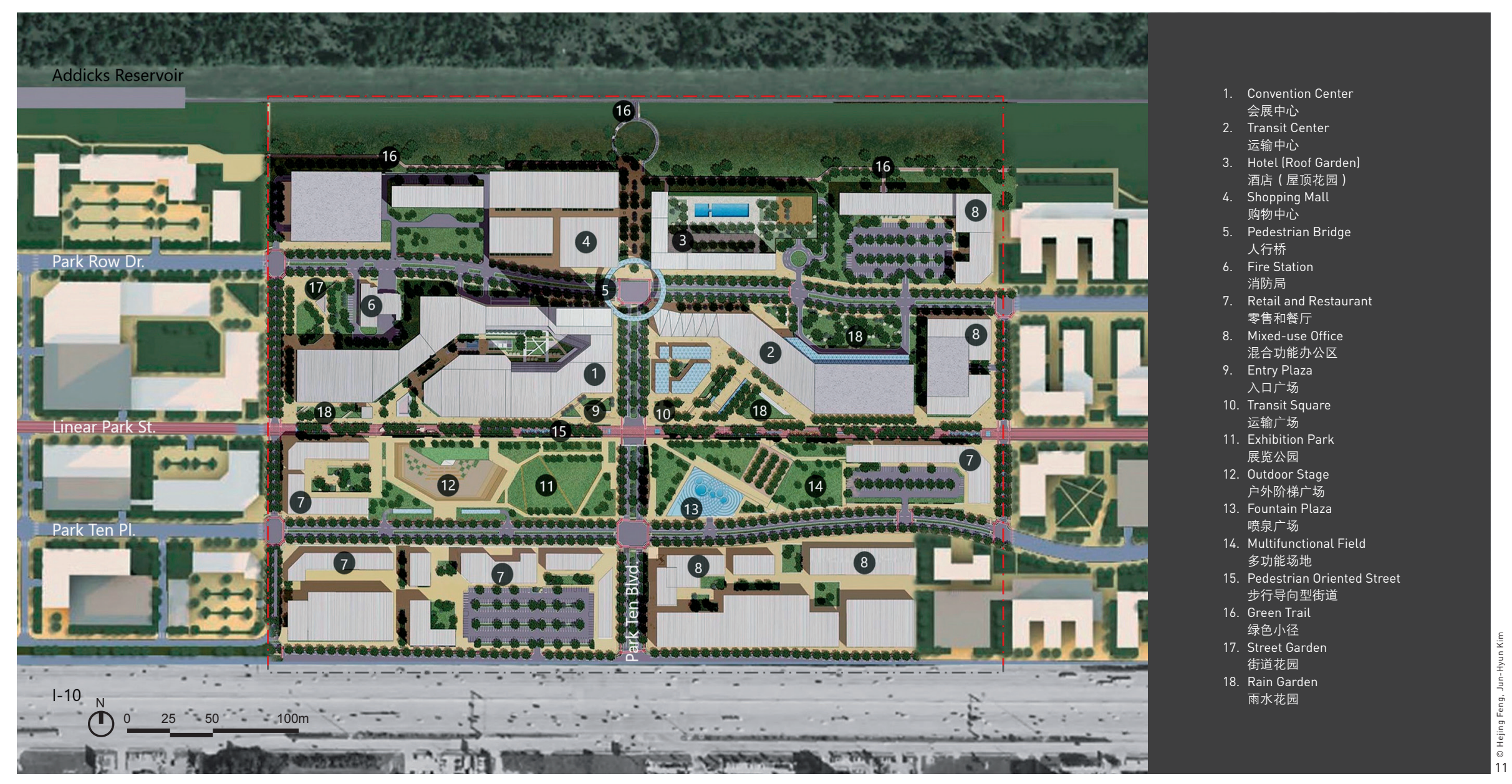

business hub located in the central area, and an innovation center at the west entrance of Park 10 (Fig. 10).

\subsubsection{The Central Business Hub}

This concentration area is designed with three objectives: 1) creating a vibrant and livable urban business center with mixed land uses and diverse destinations; 2) enhancing connectivity and accessibility by applying a gridded street network and streetscape improvements; and 3) developing a well-connected network of open space and recreational facilities. The project creates a multifunctional business hub featuring a convention center for meeting and exhibition activities, a transit center for multi-modal transportation, and a park system to encourage outdoor activities and to promote an active lifestyle (Fig. 1, 11).

\subsubsection{The Innovation Center}

Three primary design objectives guide the innovation center design: 1) creating an attractive sub-center by promoting a broad mix of land uses and innovative combinations of office, exhibition, gallery, public use and commercial spaces; 2) providing welcoming and pleasant spaces specifically at road intersections and fragmented areas, based on the existing road network and proposed building forms and functions; and 3) enhancing the pedestrian and bicycling network by providing complete streets and introducing landmarks. All are proposed to support and optimize positive community oriented values (Fig. 12).

\section{Benefits and Cost Savings}

The proposed design solutions support economic growth, social interaction and environmental benefits by using LID applications. The gridded street network incorporating complete street strategies creates attractive streetscape which provides residents and employees with pleasant walking and biking experience. Based on the amount of available data and resources, benefits are estimated that more than 22,000 dollars of annual water treatment costs can 
11. 中心商业枢纽平面图

12. 创新中心平面图

11. Master plan for the Central Business Hub

12. Master plan for the Innovation Center be saved, while the proposed trees in the green network system will bring an annual saving of 860,000 dollars on stormwater management and $\mathrm{CO}_{2}$ absorption. For the social benefits, the design introduces 125,000 feet of new bicycle lanes and increases the total linear feet of sidewalks by $900 \%$ (from 17,835 feet to 162,865 feet), which promotes community members' physical activity and offers more social interaction opportunities within Park 10. Finally, the inclusion of new office, mixed-use and residential areas will bring a significant amount of economic benefits by increasing rental revenue from approximately 356 million dollars to 533 million dollars based on the proposed plan. LAF

\section{ACKNOWLEDGEMENTS}

The authors would like to express their appreciation for the supports from the leaders of The Energy Corridor District, Mr Clark Martinson, General Manager, Ms. Fabiana Demarie, Urban Planner, and Mr. David Hightower, President. They also thank Ms. Jixing Liu and Mr. Thiago Oliveira for their help on this project.

\section{REFERENCES}

[1] Yigitcanlar, T., \& Teriman, S. (2014). Rethinking sustainable urban development: Towards an integrated planning and development process. International Journal of Environmental Science and Technology, 12(1), 341-352.

[2] Conke, L., \& Ferreira, T. (2015). Urban metabolism: Measuring the city's contribution to sustainable development. Environmental Pollution, 202, 146-152.

[3] Scott, L., \& Steve, C. (2004). Streetscape Restoration Spurs Economic Growth. Urban Land, 63, 76-77.

[4] Kim, J.-H., Ning, S., Sohn, W., Newman, G., \& Thomas, M. (2015). The Energy Corridor District comprehensive master plan, Houston, Texas, USA: A system-oriented design approach for reclaiming underutilized urban areas. Landscape Architecture Frontiers, 3(5), 82-97.

[5] Sohn, W., Kim, J.-H., \& Newman, G. (2014). A BLUEprint for stormwater infrastructure design: Implementation and efficacy of LID. Landscape Research Record, 2, 50-61.

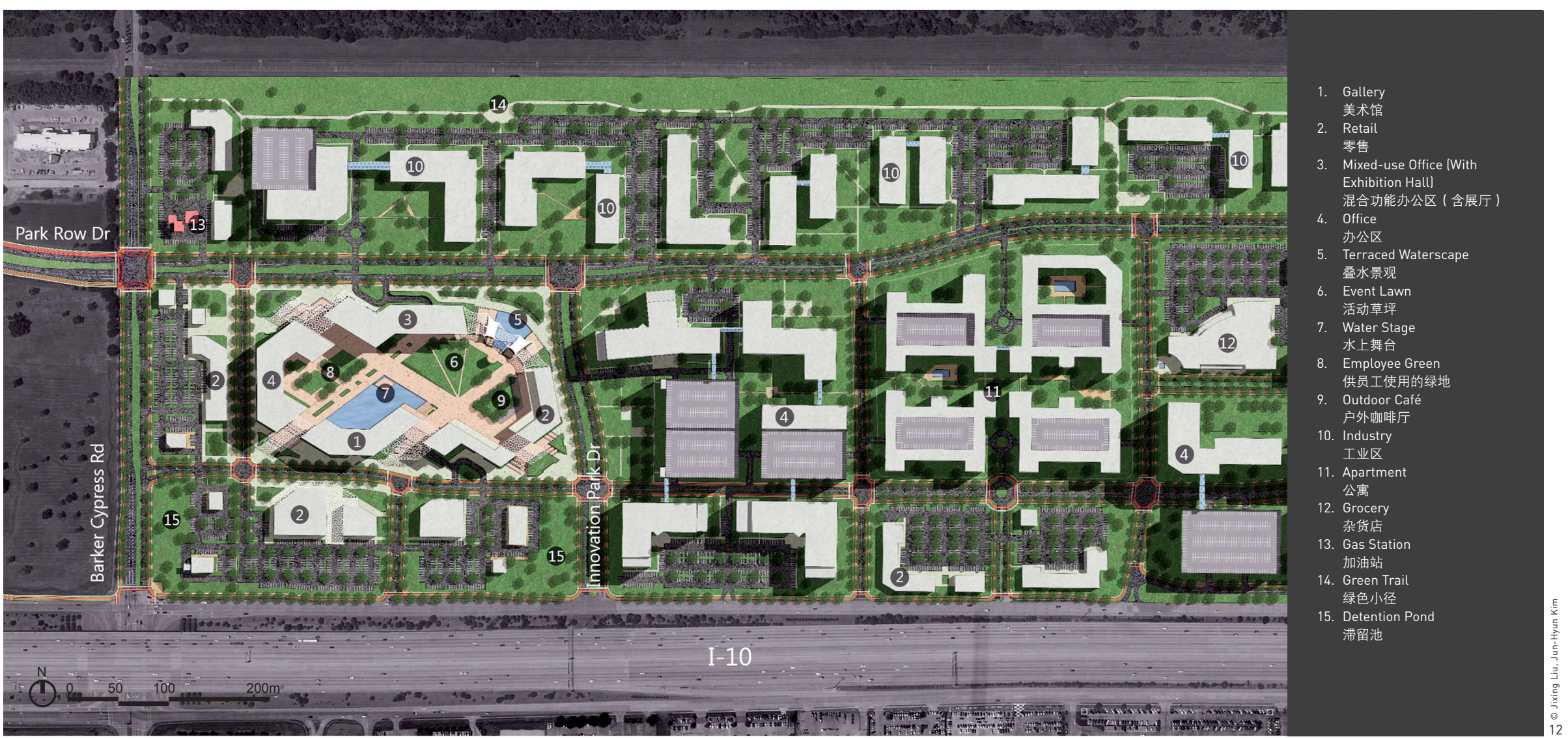

